\title{
Social-Emotional Educational Leadership: A Study of Scale Adaptation
}

\author{
Sümeyra Dilek UYLAS, Türkan ARGON
}

\section{ARTICLE INFO}

Article History:

Received 17.05.2019

Received in revised form

18.01.2020

Accepted

Available online 01.03.2020

\begin{abstract}
The purpose of this study is to adapt Social-Emotional Educational Leadership (SEL) scale into the Turkish language. The research was implemented on the 286 primary and secondary school teachers. The one-dimensional model which was consisted of 29 items was found coherent in the confirmatory factor analysis. In the adaptation study of Social-Emotional Education Leadership Scale, firstly language adaptation was done and then validity and reliability studies were conducted. Internal consistency, item and factor analysis studies were conducted to examine psychometric features of the scale. In terms of statistical validity and reliability of Social-emotional Leadership Scale, Exploratory Factor Analysis (EFA) and Confirmatory Factor Analysis (CFA) and Cronbach's Alpha techniques were utilized. The result of reliability analysis was .98 , and the scale was found reliable. Confirmatory factor analysis' results show that scale's original one-dimensional model was appropriate for the Turkish sample $\left(\mathrm{x}^{2}=1231.19, \mathrm{df}=377, \mathrm{p}=.0000, \quad \chi 2 / \mathrm{df}=3.26, \mathrm{RMSEA}=.08\right.$, $\mathrm{NFI}=.98, \mathrm{NNFI}=.99, \mathrm{CFI}=.99, \mathrm{IFI}=.99, \mathrm{SRMR}=.03, \mathrm{GFI}=.77, \mathrm{AGFI}=.74)$. In this case, the scale is considered as a reliable and valid instrument in terms of measuring social-emotional educational leadership degree in the education process of education leaders in Turkey.
\end{abstract}

(C) IJERE. All rights reserved

Keywords:

Social-Emotional Educational Leadership, Adaptation, Validity, Reliability.

\section{INTRODUCTION}

It is constantly mentioned that not only the cognitive intelligence but also emotions are important in the recent management mentality. In 1990's, with the increasing importance of the tests applied for students' success in education (Wall, 2000; as cited in Kline, 2011), the interest for the social-emotional intelligence was increased (Kline, 2011). In this context, there is a disconnection in the educational world today although the importance of social-emotional intelligence is accepted (Chopra and Kanji, 2010; as cited in Kline, 2011) as there are not enough studies in practice even though social-emotional skills are theoretically considered important (Kline, 2011).

From Darwin to today, many definitions, descriptions and conceptualizations of social-emotional intelligence include these factors (Bar-On, 2006): ability of understanding and expressing the feelings and emotions; ability of understanding what the others feel and contact with them; ability of controlling and managing the emotions; ability of managing the change, solving personal or interpersonal problems and adapting; ability of having positive impact and self-motivation. As it is understood from these abilities, social-emotional notions fit each other (Kobe, Reiter-Palmon and Rickers, 2001), and therefore, the concept of social-emotional leadership, which is a very effective and important concept, emerges with the combination of two coherent concepts, social and emotional intelligence. Social-Emotional Education Leadership is the process of influencing subordinates by using the social and emotional intelligence and the skills of social-emotional intelligence of the managers working in educational organizations.

The literature related with social-emotional intelligence based to social-emotional educational leadership (Dulewicz \& Higgs, 2000; Goleman, Boyatzis \& McKee, 2002; Kobe, Reiter-Palmon \& Rickers, 2001; as cited in Kline, 2011) supports that the business leaders who have more emotional intelligence are more successful than the others who have less, so it shows that social-emotional intelligence increases the social and academic success in today's school system (Jennings \& Greenberg, 2008; Ragozzino, Resnik, O'

Corresponding e-mail: 2sumeyradilekuylas@gmail.com, orcid.org/0000-0002-5151-3733

${ }^{1}$ Bolu Abant Izzet Baysal University,

*This article is prepared from the doctoral dissertation of Sümeyra Dilek UYLAS 
Brien \& Weissberg, 2003; as cited in Kline, 2011). This indicates the need of using social-emotional leadership skills for more efficient and effective schools.

School administrators with high social-emotional leadership will make progress by eliminating the social and academic deficiencies in the education system and contribute to positive changes in today's school systems. When the literature is reviewed, it is seen that there are limited measurement instruments about social-emotional educational leadership. So, adapting this scale into Turkish will provide great contributions to define education administrators' social-emotional educational leadership skills. In other words, the purpose of this study is to increase SEL measurement within Turkish context.

\section{METHOD}

\section{Participants}

The participants of this research included 286 primary and secondary school teachers from public schools in Hendek, Sakarya. 145 female and 141 male participants were involved in the study. Their ages ranged between 27-54 years.

\section{Procedure}

This study is a scale adaptation study. Prior to the study, necessary permission was obtained by contacting via email with the developers of the scale, Anthony Kline. The original scale consists of 6 dimension and 29 items. The scale is prepared in the 5 Point Likert type and the items are graded from 1 to 5 as follows: "Never", "Rarely", "Sometimes", "Very often", "Always". For the original scale; the coefficient of reliability of all six subscales (Relationship Skills, Self-Awareness, Responsible Decision Making, SelfManagement, Social Awareness, and Overall Influence) produced Cronbach's Alpha of 0.964. The Relationship Skills subscale, including survey questions 1, 11, 17, 24, and 29 had a Cronbach's Alpha of 0.807. The Self Awareness subscale, including survey questions 2, 4, 13, 20, and 25, had a Cronbach's Alpha of 0.763. The Responsible Decision-Making subscale, including survey questions 3, 5, 16, 22, and 27 had a Cronbach's Alpha of 0.853. The Self-Management subscale, including survey questions 6, 9, 14, 21, and 26 had a Cronbach's Alpha of 0.849 . The Social Awareness subscale, including survey questions 7, 10, 18, 23, and 28 had a Cronbach's Alpha of 0.889. Finally, the Overall Influence subscale, including questions 8, 12, 15 , and 19 had a Cronbach's Alpha of 0.870.

The scale was translated to Turkish by two language experts. Then, it was distributed as a form which contained the original items, translated items and a suggestions part to the experts in order to get their views. As experts' views, it was examined by 24 experts: 12 of them are expert teachers in original language of scale, 6 candidate teachers, 2 academicians, 1 translator, 1 sworn translator, 2 students who made their master's degree in the countries where the original scale's language is spoken. Items of the scale were improved according to the reviews of the experts. Then, the Turkish form was examined by an academician expert in Turkish Language, and the pilot Turkish form was created in the lights of this examination.

After the pilot Turkish form of the scale was created, it was started to determine whether it was equivalent to the original scale. Two methods were used to determine the linguistic equivalence of the scale. The first is the "reverse translation" method. Three people who had never seen the scale before were asked to translate the scale from Turkish into English. As a result of the evaluations, inconsistencies between the items were discussed and resolved. The second method is the linguistic equivalent form process. In this process, the original and adapted forms of the scale are applied twice to a group who speaks the language well used in the original scale (Büyüköztürk et al., 2010). The Turkish and English forms of the scale were filled out by 25 English teachers, who speak English well and work in Hendek district of Sakarya, every two weeks. This application is carried out by considering the correlation between the scores obtained. The correlation between the English and Turkish forms was .929. When this result is evaluated, it is seen that there is a very high correlation between the correlations of the English and Turkish forms of the scale $(\mathrm{r}=$ .929 ) and it could be stated that the scale had linguistic equivalence as the correlation values were found to be statistically significant.

SEL scale was implemented to measure education leaders social-emotional educational leadership level. The structure of the original scale in Turkish culture was approved by carrying out the Exploratory Factor Analysis (EFA) and confirmatory factor analysis (CFA) after assessing the validity and reliability analyses of the scale. Conformity of the data to factor analysis and multivariate normality were determined by Kaiser- 
Meyer Olkin (KMO) and Bartlett Globality Test. The coefficient of Kaiser-Meyer-Olkin (KMO) for sampling adequacy was .97 . The fact that this value is greater than .70 indicates that factor analysis can be performed on the data (Büyüköztürk, 2009). In addition to these evaluations, item-total correlations and internal consistency reliability were analyzed. Data analyses were performed using LISREL 8.54 and SPSS 22.0 software.

\section{RESULTS}

Exploratory factor analysis was done on the data related to the social-emotional education leadership scale and a single factor structure obtained as can be seen in Table 1. The scale shows a one-dimensional structure with $70.47 \%$ content validity. The fact that the variance explained in single-factor structures is above 30\% is considered to be adequate (Tabachnick \& Fidell, 2013). Büyüköztürk (2009) stated that factor load values of .45 or higher would be a good measure for the selection. When the factor loads of the items in the scale are examined, it is seen that the factor loads of all items are greater than .45 . These results indicate that the factor load values of the items are good. Item-total score correlation explains the relationship between the scores obtained from the scale items and the total score of the test (Büyüköztürk, 2009). Corrected item-total score correlations of the scale were determined according to the total scores ranging between .70 and .87 . As a result of exploratory factor analysis, it was found that the items of the scale were collected under a single factor with an eigenvalue greater than 1 . Table 1 shows the eigenvalues related to the factor analysis.

\begin{tabular}{|c|c|c|}
\hline $\begin{array}{c}\text { Social- } \\
\text { Emotional } \\
\text { Educational } \\
\text { Leadership } \\
\text { Scale Items } \\
\end{array}$ & $\begin{array}{l}\text { Factor } \\
\text { Loads }\end{array}$ & $\begin{array}{l}\text { Corrected } \\
\text { Item Total } \\
\text { Correlation }\end{array}$ \\
\hline S1 & ,81 & ,79 \\
\hline S2 & ,89 & ,78 \\
\hline S3 &, 83 &, 83 \\
\hline S4 & ,75 & ,77 \\
\hline S5 & ,70 &, 70 \\
\hline S6 &, 82 & ,79 \\
\hline S7 &, 81 &, 80 \\
\hline S8 & ,78 &, 73 \\
\hline S9 & ,86 & 85 \\
\hline S10 & ,87 &, 86 \\
\hline S11 &, 87 &, 86 \\
\hline $\mathrm{S} 12$ & ,87 &, 85 \\
\hline S13 &, 81 &, 76 \\
\hline S14 & ,84 &, 81 \\
\hline S15 &, 88 &, 87 \\
\hline S16 &, 79 &, 75 \\
\hline S17 & ,89 &, 87 \\
\hline S18 &, 88 &, 85 \\
\hline S19 & ,86 & 84 \\
\hline S20 &, 84 &, 80 \\
\hline S21 & ,80 & ,78 \\
\hline S22 & ,87 &, 86 \\
\hline S23 &, 89 &, 87 \\
\hline S24 & ,79 & ,75 \\
\hline S25 & 85 &, 84 \\
\hline S26 &, 84 &, 81 \\
\hline S27 & ,89 &, 87 \\
\hline S28 &, 87 &, 87 \\
\hline S29 &, $\mathbf{8 1}$ &, 77 \\
\hline \multicolumn{2}{|c|}{$\begin{array}{l}\text { Kaiser-Meyer Olkin Test (KMO) } \\
\text { Bartlett Globality Test }\end{array}$} & $\begin{array}{c}0,97 \\
X^{2}=6580,394 \\
P=0,00\end{array}$ \\
\hline Eigenvalue & 1 & 17,704 \\
\hline Total explained Vari & 1 & $\% 70,47$ \\
\hline
\end{tabular}


It's obviously seen in Figure 1 that the scale has one dimension. These findings indicate that the scale may have different structure in Turkish culture. Therefore, it is decided to test this one-dimension structure with confirmatory factor analysis.

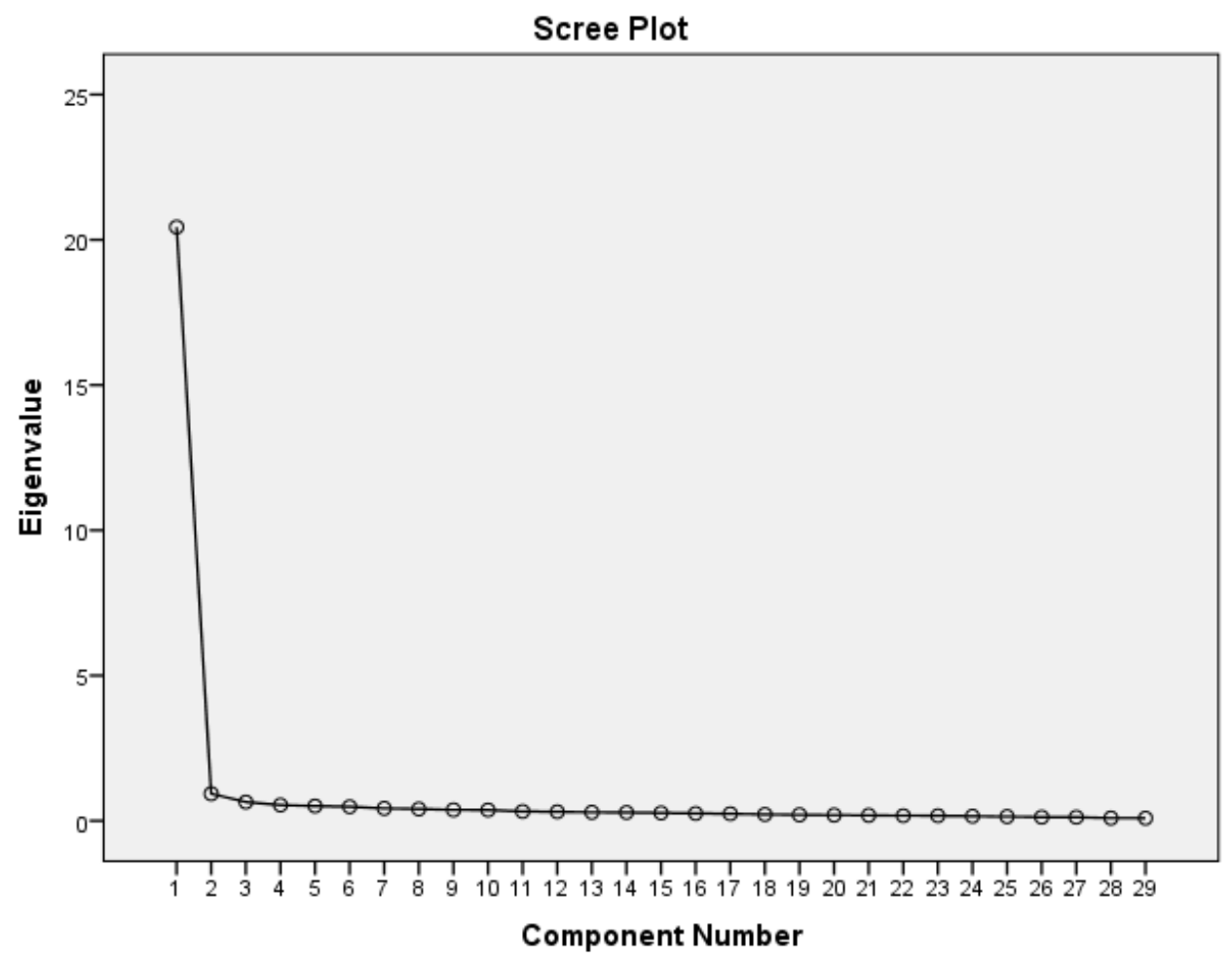

Figure 1: Eigenvalue Line Chart for Social-emotional educational leadership scale

\section{Construct Validity}

Confirmatory factor analysis is highly functional for the researchers in terms of handling apparent hypotheses like the number of factors or extents underlying its items, connections between absolute items or factors and the link between factors. To put it other way, with CFA, researchers assess "measurement hypotheses" regarding scale's internal structure. Furr and Bacharach (2008) propounded that CFA provides researchers to measure the degree to which their assessment hypotheses are consistent with the factual data of the scale. The conclusion of confirmatory factor analysis indicated that the one-dimensional model was well fit $\left(\mathrm{x}^{2}=1231.19, \mathrm{df}=377, \mathrm{p}=.0000, \chi^{2} / \mathrm{df}=3.26\right.$, RMSEA=.08, NFI=.98, NNFI=.99, CFI=.99, IFI=.99, SRMR=.03, GFI=.77, AGFI=.74). Factor loadings and path diagram for Turkish version of SEL scale are displayed in Figure 2. 


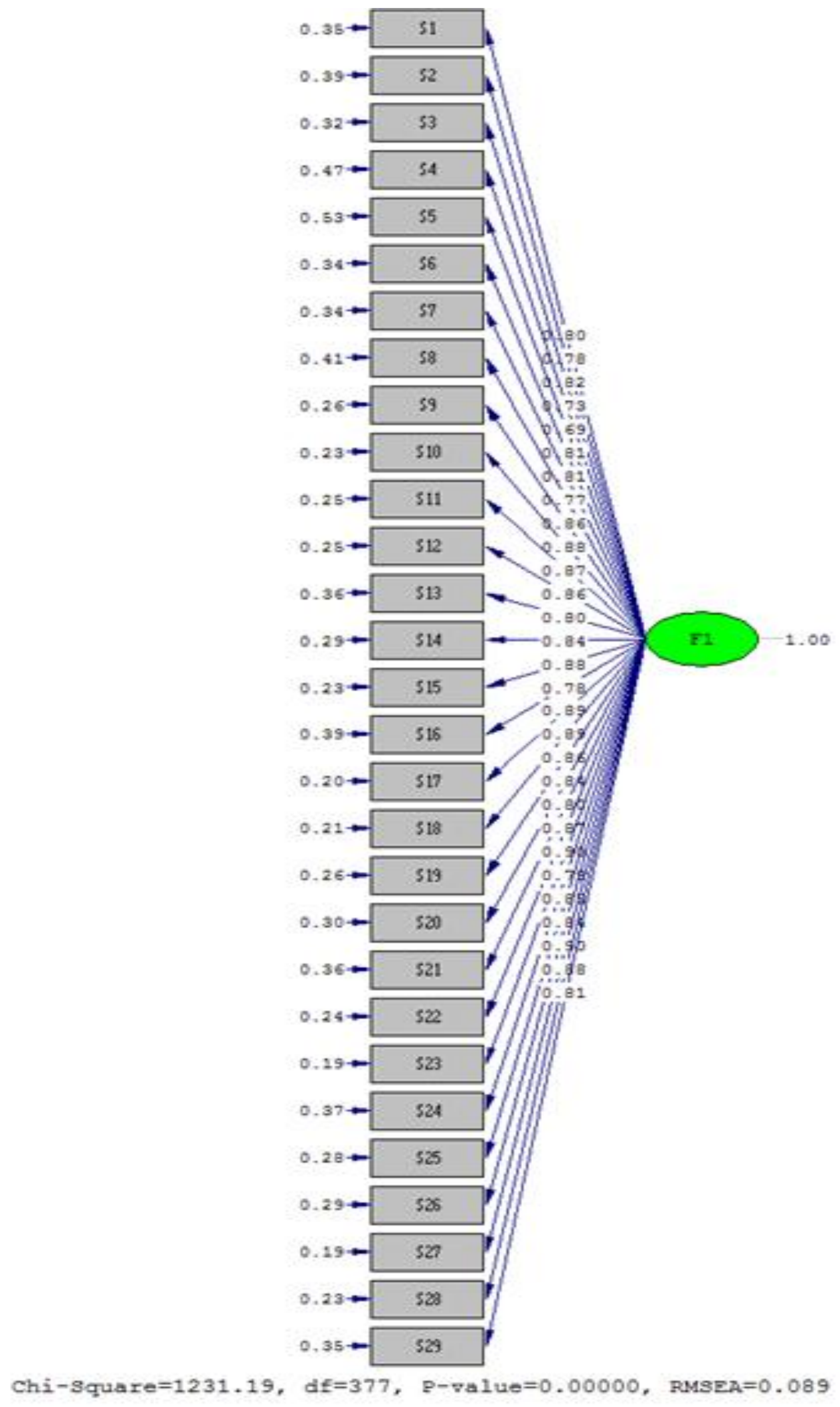

Figure 2: Factor Loadings and Path Diagram for the SEL

The results of the confirmatory factor analysis verify that the scale has one-dimension structure. The value of SRMR indicates perfect harmony. The fact that the rate of $\chi 2 / \mathrm{df}$ " is lower than 5 (Sumer, 2000) expresses that the model is coherent with real data. The fact that the values of IFI, CFI, NFI, NNFI are higher than .95 indicates perfect harmony. GFI and AGFI values should be between 0 and 1 . But it should be .90 or higher for good harmony (GFI, AGFI .90 perfect harmony; GFI> .85 and AGFI> .80 is acceptable harmony 
(Jöreskog \& Sörbom, 2004). It can be said that this study is enough for moderate compliance. In this study, it was focused on the CFI, NFI and NNFI values, in case the values of GFI and AGFI indexes can be affected by the size of sample (Şimşek, 2007). It is seen that these values are also at the level of perfect coherence $(\mathrm{CFI}=.99 ; \mathrm{NFI}=.98$; NNFI=.99). When it is evaluated in this direction, it can be said that the scale is at acceptable coherence level.

\section{Reliability}

The Cronbach's Alpha internal consistency reliability coefficients of the scale were .98 for whole scale.

\section{DISCUSSION}

The main purpose of this study was to adapt Social and Emotional Scale (SEL) into Turkish and examine its psychometric properties. The whole results of the SEL Turkish version declared reliability and validity with adaptive proficiency. According to Exploratory Factor Analysis (EFA) and confirmatory factor analysis (CFA), the research sustained that the Turkish version of the Emotional Intelligence Scale was valid and reliable $\left(\mathrm{x}^{2}=1231.19, \mathrm{df}=377, \mathrm{p}=.0000, \chi 2 / \mathrm{df}=3.26, \mathrm{RMSEA}=.08, \mathrm{NFI}=.98, \mathrm{NNFI}=.99\right.$, $\mathrm{CFI}=.99, \mathrm{IFI}=.99, \mathrm{SRMR}=.03, \mathrm{GFI}=.77, \mathrm{AGFI}=.74)$. The internal consistency reliability coefficients of the scale were calculated as .98 for the whole scale. The data of social-emotional leadership scale was analyzed with exploratory factor analysis, and it was seen that it has one factor structure. The scale with \%70, 47 content validity indicates one-dimension structure. In one factor structure, it accepted enough if the variance is higher than \%30 (Tabachnick \& Fidell, 2013). Büyüköztürk (2009) expressed that factor load values higher or equal to .45 is good criterion for the selection. When the factor loads of items were analyzed, it is seen that factor loads of all items are higher than .45 and they are between .70 and .89 . The results mean that the values of the factor loads are quite well. Item-total score correlation explains the relationship between the score obtained from scale items and total score of the test (Büyüköztürk, 2009). Being .30 or higher of item total correlation is proof for items' validity (Nunnally \& Bernstein, 1994; as cited in Güldüren, Çetinkaya \& Keser, 2016). It was determined that the scale's correlations of corrected item-total score were between .70 and .87 , this also indicates that the items have high validity.

Findings of this research are useful instruments for cross-cultural comparison as well as socialemotional educational leadership scale research within Turkey. The survey was conducted only in one county so generalizability of these results cannot be accurate with all populations in Turkey. In order to generalize the results of this research, further inquiries should be conducted with different populations and in different countries. Furthermore, future research should aim to investigate different individuals as well as a wider age range to attempt to confirm the factor structure of the scale. Although further research is needed, the findings of this study reveal that Turkish adaptation of the SEL scale is an effective tool for assessing education leaders' social-emotional leadership skills in the Turkish context with successful psychometric strength. As a result, findings of the reliability and validity tests demonstrated that Turkish version of the Emotional Intelligence Scale is valid and reliable. This research indicates that the adapted SEL is a valid data collection tool for assessing social educational leadership skills in Turkey.

\section{REFERENCES}

Bar On, R. (2006). The Bar-On model of emotional-social intelligence (ESI), Psicothema, 18, 13-25.

Büyüköztürk, Ş. (2009). Sosyal bilimler için veri analizi el kitabı (10. Baskı). Ankara: Pegem A Akademi.

Büyüköztürk. Ş., Kılıç-Çakmak. E., Akgün. Ö.E., Karadeniz. Ş. \& Demirel. F. (2010). Bilimsel araştırma yöntemleri (6. Baskı). Ankara: Pegem A Yayıncılık.

Furr, R. M., \& Bacharach, V. R. (2008). Psychometrics: An introduction. Thousand Oaks, CA: Sage

Publications.

Güldüren, C., Çetinkaya, L., \& Keser, H. (2016). Ortaöğretim öğrencilerine yönelik bilgi güvenliği farkındalık ölçeği (BGFÖ) geliştirme çalışması. İlköğretim Online, 15(2), 682-695.

Joreskog, K. G., \& Sorbom, D. (2004). LISREL 8.7 for Windows. Lincolnwood, IL: Scientific Software International. 
Argon,T. \& Uylas,S.D. (2020). Social-emotional educational leadership: A study of scale adaptation. International Journal of Educational Research Review,5(2),100-106.

Kline, A., M. (2011). Assessing the influence of social and emotional intelligence in effective educational leadership. Doctoral dissertation. Muncie, Indiana: Ball State University.

Kobe, L. M., Reiter-Palmon, R., \& Rickers, J. D. (2001). Self-reported leadership experiences in relation to inventoried social and emotional intelligence. Current Psychology, 20(2), 154-163.

Şimşek, Ö. F. (2007). Yapısal eşitlik modellemesine giriş: Temel ilkeler ve LISREL uygulamaları. Ankara: Ekinoks.

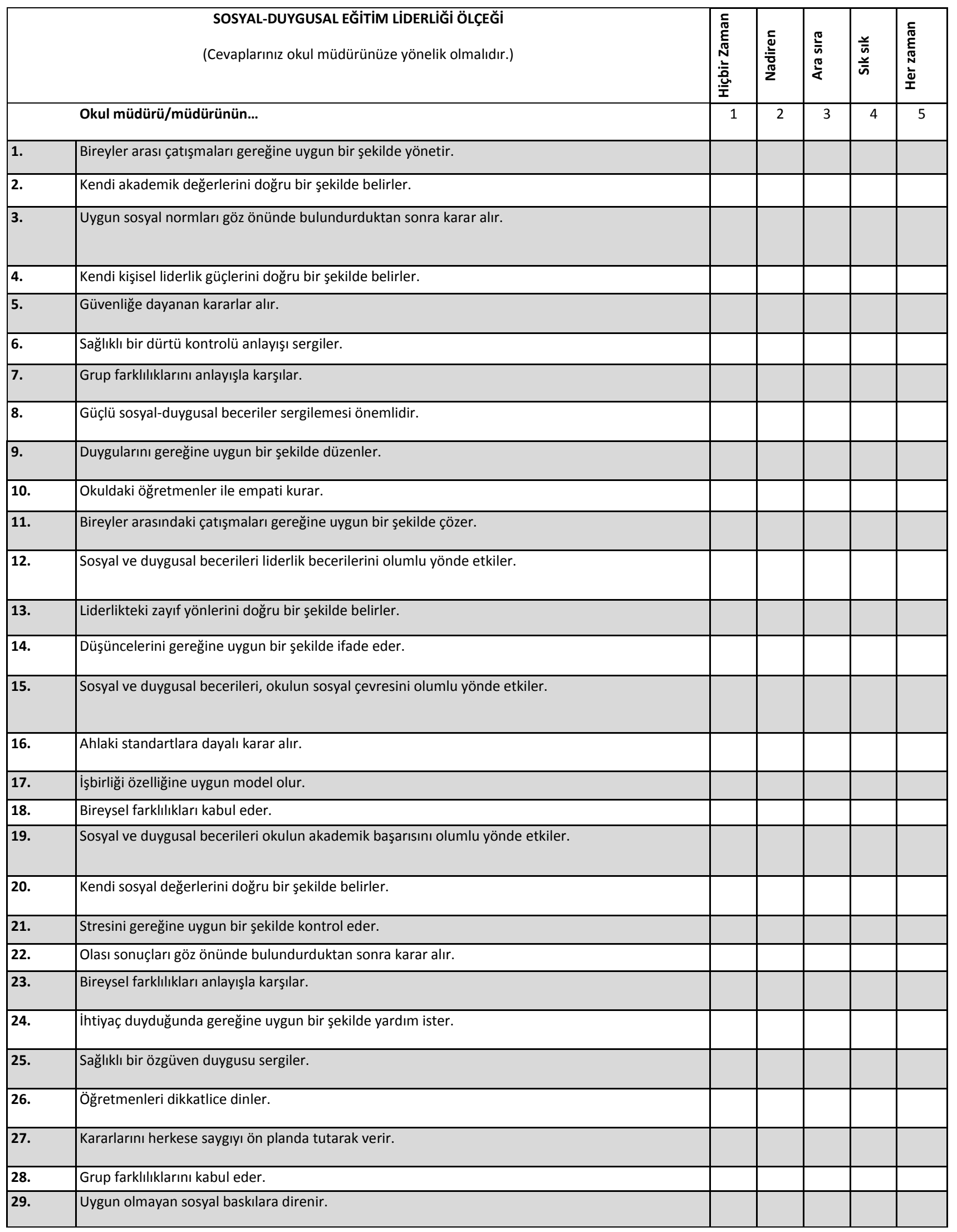

